peace sector of the economy. The producers' goods industries were, so far as possible, adapted to war production and the output of these industries was reduced. Agriculture was seriously affected by labour shortage due to mobilization, which was only in part made up by urban workers and spare-time labour. Excess purchasing power seems to have been skimmed chiefly by increased subscription to State loans. To offset the heavy losses in production resulting from Nazi occupation of European Russia, great efforts, apart from the evacuation of industrial plant and rolling stock, have been made to increase the absolute absorptive capacity of the Ural and Asiatic regions. New sources of raw materials are being exploited, new power stations established, new coal pits sunk and new oil wells drilled. New plantations of rubberbearing plants, of sugar beet, etc., have been developed, and new substitutes and methods are being employed for the manufacture of sugar and soap. In all this, scientific workers have played a great part, as well as in the simplification and rationalization of many technical processes.

\section{The Solway Tides}

A GReat tidal wave occurred on the Solway estuary on the night of December 9-10, when 3,000 acres between the Rivers Sark and Esk were under water and Sark Toll Bar marriage house was isolated, while 7 -ft. fences on Sark Foot farms were submerged. The tide was $25 \mathrm{ft}$. and was made abnormal and destructive by the wind that came in the wake of a great tidal wave. On the Scottish side the floods reached the highest recorded level since 1900 , cattle and sheep were drowned, farmhouses isolated. A 9-ft. embankment was broken in two places along the River Annan and houses were flooded in the Scottish town of Annan. It might have proved more costly but for the fact that because of the mild weather few farmers had brought their sheep down from the mountains to the estuary marshes. The Solway Firth has a history of great tides serious to local farming. Some years ago a tide with less water than that of December 9 killed nearly 1,000 sheep, owing to all the winter flocks being on the marshes. In 1942 the Solway had its usual two high tides of the year, in August and November, and the December one was unexpected.

\section{English Lakeland Fauna}

THere has been a considerable extension of our knowledge of the fauna of the English Lakeland by the activities of the Carlisle Natural History Society. A list of 292 species and sub-species has been drawn up in a manuscript book on "The Birds of Lakeland" to be published after the War, a considerable number of nesting species being added to the Rev. MacPherson's old "Fauna of Lakeland". At a recent meeting of the Society in Carlisle Museum, F. H. Day recorded six new species of Coleoptera added to the Cumberland list in 1942, bringing the total list to 1,849. The new additions are Triplax aenea, Schall.; Gabrius velox, Shp.; Aphodius constans, Duft.; Liodes glabra, King.; Hylastes opacus, Er.; and Scolytes intricatus, Ratz., from an oak log. It was also reported that in 1942 there had been an increase in the range of wall brown and peacock butterflies, also the cinnabar moth in coastal regions, while the rare greasy fritillary butterfly still maintained certain local haunts. A cream-coloured curlew nested at Hosketh Hill and the quail in a clover field at Durdar. The blackcock is still numerous in many haunts. There is a regular pied wagtail roost on the glass roof of Carlisle railway station and another roost in willows by the Caldew. The willow-tit has been recorded in a number of Lakeland localities and a grey shrike was reported from near Brampton at the end of November. Whooper swans remained on a local water until the second week of May.

\section{Earthquakes Registered in Spain}

Durnng September 1942, thirteen strong earthquakes were registered by the seismographs at the observatory at Toledo. On September 1 there were three shocks, the first beginning with $i P z$ at $9 \mathrm{~h}$. $47 \mathrm{~m}$. 34s. U.T., attaining an amplitude of $13 \mu$ on the N.S. component at $9 \mathrm{~h}$. $52 \mathrm{~m}$. 01s. U.T. and finishing at $10 \mathrm{~h}$. $50 \mathrm{~m}$. U.T. The shock apparently came from an epicentre distant $2,980 \mathrm{~km}$., the focus being some $250 \mathrm{~km}$. deep. The other two shocks were much smaller. The earthquake on September 6, which registered at $16 \mathrm{~h}$. $06 \mathrm{~m}$. 34. U. U.T., came from an epicentral distance of $9,470 \mathrm{~km}$. and that on September 9 , which registered at $1 \mathrm{~h} .37 \mathrm{~m}$. 59s. U.T., from an epicentral distance of $9,245 \mathrm{~km}$. On September 24 an earthquake which began registering at $3 \mathrm{~h} .56 \mathrm{~m}$. 34s. U.T. attained an amplitude of $11 \mu$ at Toledo at 4h. $42 \mathrm{~m}$. $46 \mathrm{~s}$. U.T. and finished recording at $5 \mathrm{~h} .10 \mathrm{~m}$. 00s. U.T. It came from an epicentre distant probably $11,710 \mathrm{~km}$. The last earthquake registered in the month was on September 26 at $4 \mathrm{~h}$. $12 \mathrm{~m}$. 09s. U.T., probably from an epicentral distance of $8,465 \mathrm{~km}$., and finished recording at $4 \mathrm{~h}$. $50 \mathrm{~m}$. U.T. The readings during the month were to a small extent confused by microseisms, and all readings are tentative.

\section{Comet Whipple}

Dr. W. H. Steavenson observed this comet on December 19, 22 and 29. On the last occasion he described it as large, at least $10^{\prime}$ in diameter, with a well-marked nucleus and a tail about $20^{\prime}$ long. Its magnitude was about 6 on December 29 . As Dr. Steavenson is at present absent from his observatory, he was able to give only approximate positions of the comet by using a 3 -in. refractor on an altazimuth mounting and estimating the positions from stars in the field. From his data Dr. M. Davidson has computed the following orbit and ephemeris, but they are only approximate owing to the nature of the observations. Those who observe the comet in the early part of the month, for which the ephemeris will probably suifice, should make the necessary corrections for later observations. The comet is approaching the earth and will be about 30 million miles away on January 28. It will almost certainly become a conspicuous naked-eye object during the month.

$$
\begin{aligned}
& \begin{array}{ccl}
\multicolumn{1}{c}{\text { Orbit }} \\
T \quad 1943 & \text { Feb. 21.20 U.T. }
\end{array} \\
& \omega \quad 57 \cdot 3^{\circ} \\
& \left.\begin{array}{ll}
\omega & 100 \cdot 2
\end{array}\right\} 1943 \cdot 0 \\
& \text { i } 20 \cdot 4 \\
& \text { q } 1 \cdot 182
\end{aligned}
$$

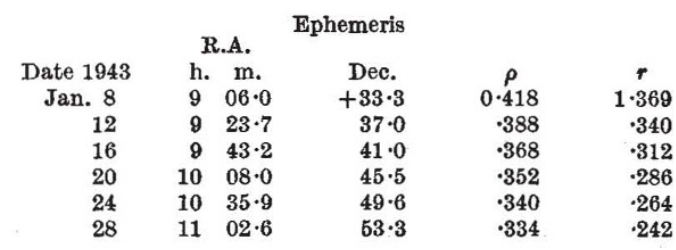

